\title{
Experience and Expectations of Prefects on Compliance with Registration Standards for First-Year Learners of Nursing Schools in the City of Mbujimayi/DRC
}

\author{
Valentin Kabambi Bukasa', Jean Paul Mbikayi Muya', Jeanne Beatrice Kaseka Cisuaka1, \\ John Willy Mpiana Baloji', Aldrin Mays Luiyanga Bin Dikuyi', Chris Kabanga Mukanya', \\ Kabeya Kalala1, Jean Pierre Kuonyi Mukendi², Jean Pierre Kufua Katukumbanyi3, \\ Etienne Tshibanda Tshibanda4, Emmanuel Mpetemba Mubala5, \\ Jean Christophe Bukasa Tshilonda ${ }^{*}$
}

\footnotetext{
${ }^{1}$ Higher Institute of Medical Techniques of Mbujimayi, Mbujimayi, DRC

${ }^{2}$ Higher Pedagogical Institute of Lukalaba, Lukalaba, DRC

${ }^{3}$ Higher Institute of Health Sciences of the Red Cross of Mbujimayi, Mbujimayi, DRC

${ }^{4}$ Higher Institute of Medical Techniques of Kalenda, Kalenda, DRC

${ }^{5}$ Higher Institute of Medical Techniques of Miabi, Miabi, DRC

Email: ^jcbukasa4@gmail.com
}

How to cite this paper: Bukasa, V.K., Muya, J.P.M., Cisuaka, J.B.K., Baloji, J.W.M., Dikuyi, A.M.L.B., Mukanya, C.K., Kalala, K., Mukendi, J.P.K., Katukumbanyi, J.P.K., Tshibanda, E.T., Mubala, E.M. and Tshilonda, J.C.B. (2021) Experience and Expectations of Prefects on Compliance with Registration Standards for First-Year Learners of Nursing Schools in the City of Mbujimayi/DRC. Open Access Library Journal, 8: e7168.

https://doi.org/10.4236/oalib.1107168

Received: February 8, 2021

Accepted: March 28, 2021

Published: March 31, 2021

Copyright $\odot 2021$ by author(s) and Open Access Library Inc.

This work is licensed under the Creative Commons Attribution International License (CC BY 4.0). http://creativecommons.org/licenses/by/4.0/

\begin{abstract}
Introduction: The goal of this work is to understand the experience on the respect of the standards of registration of the learners in first nurse with the prefects in order to make proposals for the improvement of conditions of registration in relation to the prescribed standards. Method: The study is qualitative. The method used in this study was phenomenological. The data were collected cross-sectionally using a recording device. This data collection concerned 8 prefects of nursing schools in the town of Mbujimayi. The sample was of the reasoned type. Results: Regarding the experience of the prefects on the registration conditions for most school heads: 1) We often check the authenticity of the school piece and then certain mentions such as: a) The application; b) Driving. 2) They are finally organizing the entrance exam. In relation to their expectations, the Heads of establishment want: a) That the age limit for admission be respected; b) That actual minimum and maximum not be taken into account. Conclusion: Because the experience of the prefects on the conditions of registration is based on the verification of the application and the conduct to certify the authenticity of the school piece and their expectations would be that the age limit for admission is respected and that the minimum and maximum numbers are not taken into account, the head of
\end{abstract}


the establishment must bear in mind that he is "the only person responsible for registrations". Alone, he admits or refuses the learners presented to him. It remains true that the last word comes back to him.

\section{Subject Areas}

Education, Nursing

\section{Keywords}

Experience, Expectation, Standards, Prefect, Nursing Schools

\section{Introduction}

The nursing profession is highly regulated and requires both technical skills related to medical acts, and both human and relational qualities that must be learned in medical education institutions [1].

Among the reason for the change of school by the learners is the recommendation to enroll a pupil by the authorities. However, KANKU KAMAYOYO [2] writes in his study that the recommendation of a pupil by an authority does not mean his automatic registration.

Thus the first task of inspectors at both primary and secondary level is to travel through all schools, to verify the authenticity of student reports as well as teachers' academic qualifications in order to detect all counterfeiters [3].

This inspection of capital importance must also take place in nursing schools, especially since these schools require the most extreme rigor in the selection of the files of the learners because they will study to treat humans and are not entitled to the mistake.

To have access to studies and hang up his state nursing diploma, the heads of these schools are required to take seriousness and rigor in the selection of files for registration. It is a job with responsibilities, which requires a strongly personal motivation. Thus the needy must undertake nursing training studies in dignified schools with discipline and rigor [4].

In addition, the nursing schools of the Democratic Republic of the Congo have been governed by the reform programs since 2009. In fact, since the 2009-2010 academic year, the admission to the first graduate of candidates graduating in humanities obtained with less of $60 \%$ is conditioned by the passage to the entrance examination and this is according to the ministerial decree $n^{\circ} 68 / M I N I S U / C A B M I N / 2009$ [5]. And the student chooses any section or option, without an orientation or experience requirement.

So faced with a problem of this kind, we wanted to seek to understand the reality in the enrollments and the selection of students who must be enrolled in medical schools with heads of establishments of ITMs in the city of Mbuji-Mayi. 


\section{Method}

This study is qualitative and uses the phenomenological method which helped us to explore the different experiences and expectations of the prefects on the respect of the standards of enrollment of learners in first year in nursing schools. Data were collected cross-sectionally by means of a recording. This data collection was carried out through questions asked to the prefects of 8 nursing schools in the town of Mbujimayi.

The sample was a reasoned type, it consisted of 8 prefects who were part of this study and were taken from the target population in accordance with the selection criteria. This type of sample was thus chosen because initially we had selected for interview informants with a broad general knowledge of the subject or those who have been experienced and whose experience is considered typical.

\section{Results}

\subsection{Sociodemographic Characteristics of the Respondents}

Table 1 shows that most prefects were men $75 \%$ and $62.5 \%$ of prefects $\mathrm{BC}$ have an age between 46 and 56 years old. $75 \%$ of the Prefects fl have the graduated and finally $87.5 \%$ had an experience between 13 and 20 years.

\subsection{Development of the Themes or Variables of the Study Itself}

From the thematic analysis, six variables emerge that we have taken as main themes in this study, namely:

- Assessment of the admission criteria in force;

- The selection of the best candidates on the basis of these criteria;

- The assessment of the current level of the candidates who take the entrance examination;

- Adaptation of the competition in relation to the level of the candidates;

- Judging the progress of the admission process to the school;

- The assessment of the way in which the recruitment of pupils of the $1^{\text {st }}$ is satisfactory.

These themes emerge statements prefect and experience on learner recruitment conditions in $1^{\text {era }}$ nurse. And each theme brings out categories according to the responses to the surveys, faithfully reporting the significant descriptions or the full report otherwise called verbatim.

In addition, we have organized these data by reducing their volume into smaller and more powerful units that can be processed, described, interpreted and presented in an understandable way [6] [7].

The thematic analysis of the expectations of the prefects who proposed well-selected candidates capable of completing medical studies and not those unable to finish the cycle who could work anarchically to kill the sick. The involvement of everyone in the training of future nurses (parents, prefects and students). Avoid selling or buying fake school coins (Table 2, Table 3). 
Table 1. Sociodemogrphic characteristics of the respondents.

\begin{tabular}{cccc}
\hline Variables & Modality & Work force $\mathrm{n}=8$ & Frequency (\%) \\
\hline \multirow{2}{*}{ Sex } & 1) Male & 6 & 75 \\
& 2) Feminine & 2 & 25 \\
Age (Years) & 1) $46-56$ & 5 & 62.5 \\
& 2) $57-67$ & 3 & 37.5 \\
Qualification & 1) Graduated & 6 & 75 \\
& 2) Licensee & 2 & 1 \\
Seniority & 1) $5-12$ & 7 & 12.5 \\
\end{tabular}

Table 2. Prefects' experience.

\begin{tabular}{|c|c|c|}
\hline THEMES & CATEGORIES & VERBITIM \\
\hline $\begin{array}{c}\text { Prefects' } \\
\text { experiences }\end{array}$ & $\begin{array}{l}\text { Assessment of the } \\
\text { listing requirements }\end{array}$ & $\begin{array}{l}\text { - For me, the conditions have changed, you must register students who complete the } 4^{\text {th }} \text { and } \\
3^{\text {rd }} \text { humanities in } 1^{\text {st }} \text { nurse }\end{array}$ \\
\hline $\begin{array}{l}\text { on registration } \\
\text { conditions }\end{array}$ & $\begin{array}{l}\text { of learners in } \\
1^{\text {st }} \text { nurse }\end{array}$ & $\begin{array}{l}\text { - I think the level is too low, long before the candidates were recruited after finishing the } 4^{\text {th }} \\
\text { and for the moment the students are recruited after having finished the } 3^{\text {rd }} \text { of humanities }\end{array}$ \\
\hline
\end{tabular}

Table 3. Expectations of prefects.

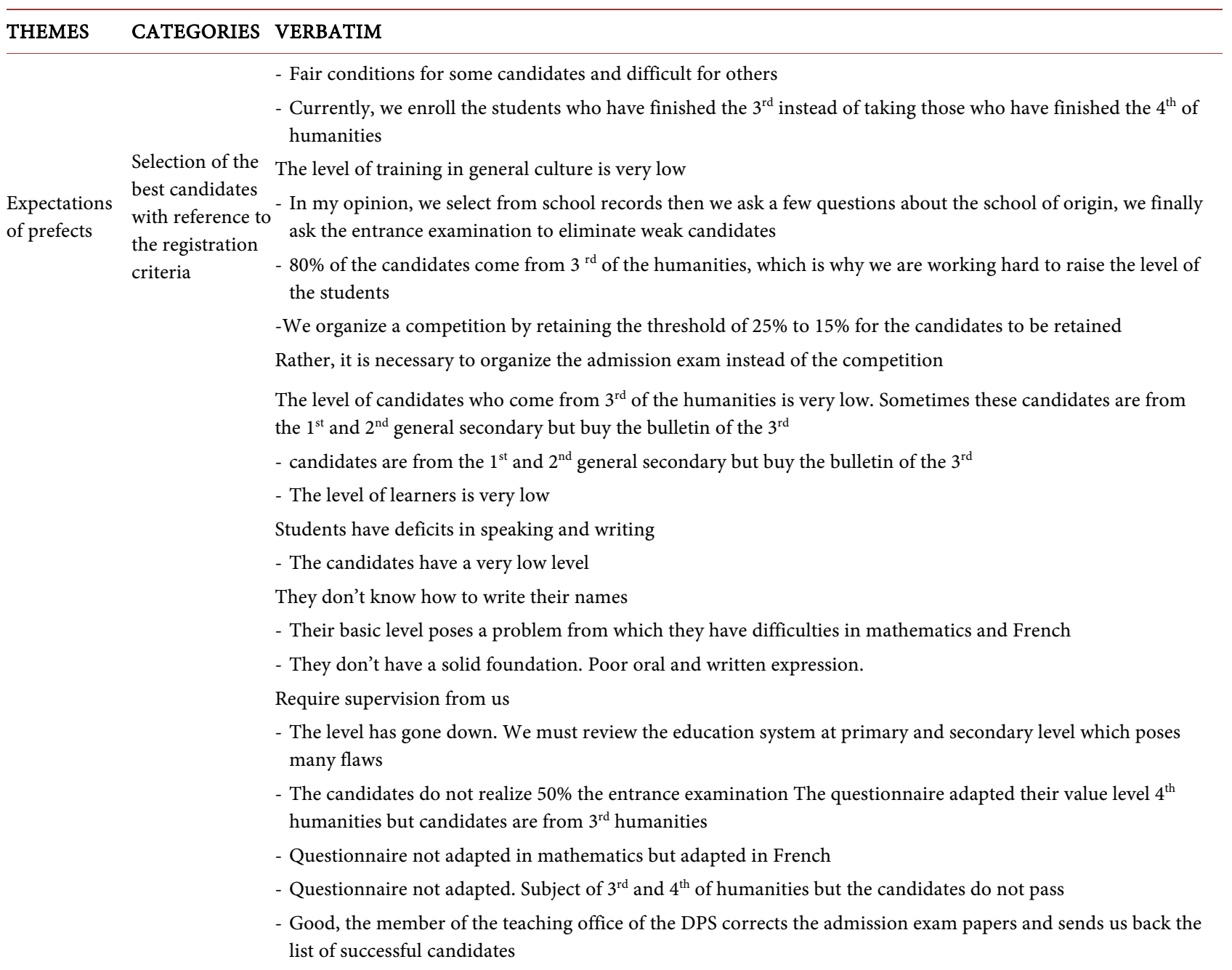


- We register on the basis of assessment of the files presented by the candidates and then we organize the entrance examination

- No enthusiasm for the flow, candidates come gradually but the time allotted is insufficient

- The coordination of ITMs at the DPS level takes care of it and is going well. But no feedback on the results It is necessary to recruit learners who have completed the $4^{\text {th }}$ and not the $3^{\text {rd }}$ of humanities

- We ourselves assess the files before registering the candidates

- That the DPS let the school organize the competition and send the results to the DPS

- We are satisfied because the candidates go through a competition

P1. It is necessary to recruit the pupils able to finish the studies to avoid the phenomenon of charlatan in the village

P2. Everyone needs to be involved, parents need to avoid buying report cards for their children, school officials need to take school management seriously and avoid selling fake coins

P3. The coordination of the competition changed by an admission exam

P4. Enroll only students who have a solid foundation and not those who are weak and come with the school titles purchased

Take into account good schools of origin

P5. Objectively organize the admission exam

Retain no more than 50 students

Take into account certain mentions found on the bulletins:

- Conduct and enforcement

Only enroll $4^{\text {th }}$ year humanities learners.

\section{Interpretations and Discussion of Results}

\subsection{Results in Relation to the Socio-Demographic Characteristics of the Respondents}

Most of the Prefects were men, i.e. 75\%. This is explained by the fact that in the province of Kasai Oriental, the studies of boys were more privileged than that of girls. $62.5 \%$ of the prefects were between 46 and 56 years old. This age group is considered as the one with a long professional experience to which it is more preferable to entrust courses in the field of education. $75 \%$ of the Prefects were graduates and finally $87.5 \%$ had experience between 13 and 20 years. This is justified by the fact that the higher institutions of medical techniques which have been operating for several years in the province, have already launched a large number of graduates in the field compared to the graduates who are injected not long ago.

\subsection{Results in Relation to the Variables of the Study}

\subsubsection{Experiences of Prefects}

6 categories of experience emerge from this category on the experience of prefects; it is about:

1) Management of the process for learners to meet registration criteria.

In the light of the results obtained, the prefects surveyed provided the answers in the following ways:

- For some, the registration conditions are fair for some learners and difficult for others;

- Others say first nurse learners should be recruited after completing fourth 
general humanities. The change of these criteria, to take the learners of the third secondary instead of the fourth secondary makes that the latter experience the difficulties of adaptation because they have no notions of general cultures. These declarations comply with Art 7, 8, 49 and 50 of ordinance $n^{\circ}$ 67-230 of May 11, 1967 on implementing measures for ordinance law $\mathrm{n}^{\circ}$ 66-299 of May 14, 1966, relating to education. medical and paramedical technique [8].

\section{2) criteria to properly select the best candidates}

Several prefects interviewed declared that the registration criteria should be reviewed; the others suggested changing the name of the competition to an admission exam because the competition is not eliminatory, it already sets the learner quota.

3) Assessment of the current level of learners who take the entrance examination for ITMs

The prefects surveyed are certain that the level of the learners who take the entrance examination is very low, they cannot read and write, and did not have a solid foundation in primary and general secondary. Others say it all depended on the school from. These statements go hand in hand with the result of the study conducted by Charles Gardon [9] which says the qualities of teacher training and development largely determine the quality of student education.

4) Adaptation of the admission examination questionnaire to the level of the learners

Some confirm that the questionnaire is adapted to the level of learners of third nurse and others affirm that the questionnaire is not adapted because their level is very low [10]. Some are doing well in mathematics and others have deficiencies in French.

5) Judgment on the progress of the admission process in ITMs

Respondents say the admission process in the ITM is going well, but the final decision rests with the Division Provinciale the Sante through Bffice Teaching Health Sciences (BESS) that handles proofreading and report the results in the ITM according to the guidelines of the $6^{\text {th }}$ Board of Education of Health Sciences [11].

6) Satisfaction with the manner of recruiting first year learners in ITMs

The prefects suggest that the coordination compose the admission examination questionnaire and let the ITMs take care of the correction of the admission tests [12].

\subsubsection{Prefect Expectations}

\section{1) Opinion to be issued on the admission criteria for ITM learners}

The prefects propose to return to the old system, that of recruiting only learners coming from the fourth year of the humanities and not from the third year.

Others say that the admission criteria are adequate, third secondary applicants from serious schools pass without problem.

We must carefully select the candidates on the basis of the files check the 
mention; failure, application and conduct of the learner. This wish joins that of Mwilambwe Mukala Wankulu [9].

\section{2) Wish for respect}

- They must verify the authenticity of school records, rule out false documents presented at registration. This wish joins the statement of Amuli [10] which requires the verification of the authenticity of a piece of a student coming from another establishment.

Do not retain bloated staff in order to make revenue profitable. Retain candidates capable of starting courses and finishing studies according to KombaDjeko [11].

\section{Conclusions}

The head of the establishment must bear in mind that he is "the only person responsible for registrations". Alone, he admits or refuses the learners presented to him. It remains true that the last word comes back to him.

The sine qua non for admission is the presentation of authentic and original school documents, rigorously checked by the school administration. Any anomalies noted at the time of registration will be attributed to him.

\section{Conflicts of Interest}

The authors declare no conflicts of interest regarding the publication of this paper.

\section{References}

[1] Gerard (2014) Responsibility in Education: Transformations, Ruptures and Contradictions. 41, 158-159.

[2] Kanku Kamayoyo, N. (2006) Management of a School Establishment. Talenta Edition, Lubumbashi.

[3] Mvwendy Mabelintu, F. (2010) Tasks of the Inspector in Education, Inédit, Kinshasa.

[4] Unicef (2007) The Situation of Children in the World.

[5] Mbikayi, M., et al. (2012) Instructions on the Admission of Pupils to the First Year at EPSP, Inédit, Kinshasa.

[6] Fortin, M.H., et al. (2010) Scientific Research Methodology in Care.

[7] Ordinance Law ${ }^{\circ}{ }^{\circ} 66-299$ of May 14 (1966) Relating to Medical and Paramedical Technical Education.

[8] Gardon, C. (2003) Handicap: Raising Awareness, Informing, Training.

[9] $6^{\text {th }}$ Directorate of Education of Health Sciences (2015) Instructions on the Entrance Examination.

[10] Wankulu, M.M. (1997) Admission of Students to School, Inédit, Lubumbashi.

[11] Jiwe, A. (2018) Administration and Organization of Nursing Schools, Inédit, L2 EASI, ISTM/Mbujimayi.

[12] Djeko, K. (2017) Organization of ITM/EEM Admission Exams, Kinshasa Gombe. 